\title{
FORTIFICACIONES, ELEMENTOS DEFENSIVOS Y ORGANIZACIÓN MILITAR \\ EN LOS FUEROS CASTELLANOS Y LEONESES DE LA EDAD MEDIA (SIGLOS XI-XIII)
}

\author{
$M^{2}$ CONCEPCIÓN CAstrillo Llamas \\ Universidad Complutense de Madrid
}

\section{SUMARIO}

Introducción.- 1. Los representantes del poder monárquico ante el concejo. 1.1. El dominus villae. 1.2. El alcaide. 1.3. El palatium.- 2. Las fortificaciones: cuidado y mantenimiento de los elementos defensivos.- 3. La organización militar de los concejos y su participación en las actividades bélicas. - Conclusiones.

\section{INTRODUCCIÓN}

La utilización de los fueros municipales como fuente para el estudio de diversos aspectos relacionados con la época medieval no es un fenómeno nuevo. Los especialistas en Historia del Derecho así como los historiadores de la Edad Media se han apoyado continuamente en estos textos para llevar a cabo trabajos de gran relevancia; sin embargo, todavía brindan numerosas posibilidades de estudio a los investigadores.

La mayor parte de los textos forales muestran una normativa específica destinada a regular la organización militar y defensiva de las localidades a las que fueron otorgados. Frecuentemente, en ellos se hace referencia al dominus villae o tenente, al alcaide, a los dispositivos de vigilancia o a la reparación de muros y fortificaciones. No obstante, son 
escasos los trabajos que han abordado directamente esta temática ${ }^{1}$, circunstancia que resulta sorprendente si se tiene en cuenta que la mayoría de los concejos que recibieron fueros entre los siglos XI y XIII estuvieron dotados de importantes fortificaciones y de elementos defensivos que condicionaron su posterior evolución. Por otra parte, parece obvio que estos textos constituyeron la base del primitivo Derecho militar, tal y como señalo hace algunos años Salvador de Moxó ${ }^{2}$.

La interesante normativa contenida en los fueros me ha llevado a plantear una hipótesis de trabajo que contempla a éstos como una de las $\mathrm{r}$ afces jurídicas de la tenencia de fortalezas. Esta institución, cuyos orígenes se remontan a los comienzos de la Reconquista ${ }^{3}$, permaneció muy arraigada en la Corona de Castilla durante toda la Baja Edad Media, según han puesto de relieve en los últimos años varios investigadores ${ }^{4}$. Las Siete Partidas de

\footnotetext{
'Sirvan como ejemplo los trabajos de N. GUGLELMa, El dominus villae en Castilla y León, "Cuademos de Historia de España", (en lo sucesivo "CHE"), XIX (Buenos Aires, 1953), pp. 55-103, J. MUÑoz RUANO, Los castiellos e las fortalezas en el ordenamiento juridico de las Partidas, "Toletum", 22, vol. 71 (Toledo, 1988), pp. 123-141.

${ }^{2}$ S. de MoxO, El Derecho Militar en la España cristiana medieval, "Revista Española de Derecho Militar", 12 (Madrid, 1961), p. 13.

${ }^{3} \mathrm{H}$. GRASSOTt1, Las instituciones feudovasalláticas en León y Castilla, II, Spoletto, 1969. p. 706.

'J. PAZ Y MELÁ, Castillos y forzalezas del reino. Noticias de su estado y de sus alcaides durante los siglos XV y XVI, Madrid, 1978; H. GRASSOTTI, Sobre la retenencia de castillos en la Castilla Medieval, "Miscelánea Charles Verlinden. Bulletin de l'Institut Belgue de Rome", XLIV (Bruxelles-Rome, 1974), pp. 283-299; C. GONZALEZ MINGUEZ, Sobre la retenencia de los castillos de Arganzón y Zaldiarán, "Príncipe de Viana", 37 (Pamplona, 1976), pp. 197-206; C. AlVAREZ ÁlVAREZ, Tenencia de fortalezas reales asturianas por la Casa condal de Luna, "Asturiensia Medievalia", 4 (Oviedo, 1981), pp. 197-216, M.A. LADERO QUESADA, Les fortifications urbaines en Castille aux $X^{+m}-X V^{m}$ siécles: Problématique, financement, aspects sociaux, "Fortifications, portes de villes, places publiques dans le monde mediterranéen", Ed. J. HeErs, Paris-Sorbonne, s.a., pp. 145-176; $M^{*} \mathrm{C}$. QUINTANILla Raso, La tenencia de fortalezas en Castilla durante la Baja Edad Media, "En la España Medieval", V, 2, (Madrid, 1986), pp. 861-895, Consideraciones sobre las fortalezas de la frontera castellano-portuguesa en la Baja Edad Media, "II Jornadas Luso-Espanholas de Historia Medieval", I, Porto, 1987, pp. 401-430, Acerca de las fortalezas en la frontera granadina durante el siglo XV, "IV Coloquio de Historia Medieval Andaluza", Almería, 1988, pp. 251-272; J.E. LOPEZ DE COCA, Tenencia de fortalezas en el reino de Granada en época de los Reyes Católicos (1492-1516), II, "El Reino de Granada en época de los Reyes Católicos: Repoblación, comercio y frontera", Granada, 1989, pp. 235-269; F. GARCIA FITZ, Notas sobre la tenencia de fortalezas: los castillos del concejo de Sevilla en la Baja Edad Media, "Historia. Instituciones. Documentos", 17 (Sevilla, 1990), pp. 55-81; M. DIAGO HERNANDO, El alcaide Juan de Luna: un hombre al servicio del condestable don Álvaro de Luna en la región soriana, "Celtiberia", (Soria, 1991), pp. 59-85; N. CASQUETE DE PRADO, Los castillos de la Sierra Norte de Sevilla en la Baja Edad Media. Aproximación histórica, Sevilla, 1993; $M^{*} \mathrm{C}$. CASTRILL LlaMAS, Alcaides, tenencias y fortalezas. Evolución de una institución y relaciones de poder en Castilla (Siglos XIII-XIV), (2 vols., Madrid, 1993), Memoria de Licenciatura inédita.
} 
Alfonso X El Sabio ofrecen la primera legislación sistematizada referida a los castillos y las fortalezas, aunque ésta parece inspirarse en algunos de los preceptos recogidos en los textos municipales: por ejemplo el delito de traición del castillo, la reglamentación de los servicios de vigilancia o las obligaciones del alcaide son contenidos que se encuentran implícitos en los fueros $y$ en ocasiones bastante desarrollados. Estas disposiciones fueron especialmente abundantes en los textos otorgados a las Extremaduras, cuya destacada posición fronteriza influyó decisivamente en su estructura polítir. militar.

En este trabajo se pretende estudiar el significado y alcance de estos preceptos así como su posible proyección en la legislación posterior, mucho más amplia y abundante. Para llevar a cabo este objetivo se han manejado las ediciones de algunos de los principales fueros municipales de los siglos XI al XIII otorgados a diversas localidades castellanas y leonesas, lo que ha permitido establecer numerosas comparaciones y diferencias entre zonas geográficas muy distintas; sin embargo, por razones de espacio no se han inclurdo los textos otorgados a villas y ciudades andaluzas. En definitiva, se trata de una nueva faceta de análisis hasta ahora poco conocida, pero que, como podrá comprobarse, reviste gran interés y aporta nueva luz sobre los orígenes institucionales de la tenencia de fortalezas.

\section{LOS REPRESENTANTES DEL PODER REAL ANTE EL CONCEJO}

La monarquía ejerció su autoridad en los concejos castellanos y leoneses a través de dos oficiales: el dominus villae y el alcaide, que desempeñaron funciones gubernativas y militares respectivamente, y por medio de una importante instancia de poder que fue el palatium con un sentido simbólico y defensivo. Los fueros municipales incorporaron algunos preceptos muy interesantes sobre estos aspectos a los que están dedicados las siguientes páginas.

\footnotetext{
'Las Siele Partidas del Rey don Alfonso el Sabio, cotejadas con varios códices antiguos por la Real Academia de la Historia, 1807, Madrid, 1972, 3 vols., véase en particular Partida II, 18, Leyes 1 a 32 .
} 


\subsection{El "dominus villae"}

Como es bien sabido, durante los siglos XI y XII los monarcas castellanos y leoneses se sirvieron de determinados funcionarios para gobernar las distintas demarcaciones territoriales de ambos reinos denominadas tenencias. El dominus villae se situaba al frente de una villa o ciudad y de su correspondiente alfoz: también denominado tenente o senior, se halla presente en la mayor parte de los fueros estudiados desempeñando funciones militares, tributarias, judiciales y administrativas, por lo que se convirtio en una pieza esencial del entramado político-administrativo de los reinos de Castilla y de León". A partir del siglo XIII las nuevas circunstancias obligaron a la monarquía a prescindir de estos individuos, que fueron sustiturdos en muchas de sus funciones por otros oficiales controlados directamente por el rey. Esta evolución se aprecia claramente en los textos forales de distintas zonas geográficas, como podrá comprobarse a continuación.

Algunos Fueros otorgados a localidades situadas en el reino de León se ocupan con bastante detenimiento del dominus villae?. Así, en Ledesma este personaje actuaba en nombre del rey y tenia la obligación de impulsar la repoblación del territorio, protegla a los habitantes, evitaba que éstos se pusiesen bajo el señorío de caballeros o de establecimientos eclesiásticos so pena de traición y pérdida de los bienes ${ }^{8}$, y mantenía el orden y la justicia?. En Alba de Tormes el tenente prestaba juramento ante los Evangelios y se

${ }^{6} \mathrm{~N}$. Guguelma, Op. cit. (nota 1), p. 55. Sobre los orígenes de este personaje véanse: L. Garcla de Valdeavellano, Curso de Historia de las Instituciones Españolas, Madrid, 1986, pp. 541, 542, 567, 570 y 677, C. SÁNCHEZ ALBORNOZ, Imperantes y potestates en el reino astur-leonés (718-1037), "CHE", XLV-XLVI (Buenos Aires, 1967).

7"Esto mando el rey don Femando por fuero, e Fernan Rodriguez, que tenja la onor en Ledesma e en sus terminos: deytaron querenllas en tierra, que poblasen todos los villares, e los pobladores seeren posteros del rey. Alcalldes den entre los villares terminos e mayadas de ganados, huertos, linares, prados, ferrenes, partan todos por fuertes; los montes e los terminos non los defenda nullo omne con enbelgas. Quien heredare defendir, defendala con reya iunta e ayala. Et quien quadrjellas demandar o con enbelgas tierras anparar, peche.$X$. moravedis e nonlle preste", A. CASTRO \& F. DE ONIS, Fueros leoneses de Zamora, Salamanca, Ledesina y Alba de Tormes, Madrid, 1916, cap. 246, p. 260.

"Todos omnes moradores de Ledesma e de sus terminos que heredades an so el rey e su conceyo, e con ellos se alçar, e metense su cavalleros e su freyres e so bispos e so monges, por tal que non sirvan al rey o al sennor quela onor tovier con conceyo, picrda ela heredade e ixea por traedor del rey quelle dio la heredade e del conceyo; e el conceyo de ela heredade aquien sirva al rey con ellos e al sennor que tien la onor", lbidern, cap. 320, p. 272.

'Ibidem, cap. 367 , p. 281. 
comprometía a no cometer ahusos contra la población y a respetar su fuero. En caso de incumplir estos requisitos no serfa recibido en la villa ni se le daría la remuneración correspondiente ${ }^{10}$. Además, el dominus percibía los dos tercios de las calonas del querelloso" ${ }^{11}$ y 100 sueldos por el arrendamiento de la moneda forera ${ }^{12}$.

A partir del siglo XII la administración territorial sufrió una transformación de su estructura motivada por el desarrollo de los señoríos dotados de inmunidad y por la influencia de los principios feudales. La monarquía concedió entonces el gobierno y la administración de un territorio en beneficio o patrimonio como un derecho de disfrute o tenencia a título temporal o vitalicio -régimen que ya venía siguiéndose en Navarra y Aragón con el nombre de honor ${ }^{13}$. Esta fórmula se convirtió en la base de la administración territorial de los reinos de León y de Castilla ${ }^{14}$.

Esta misma realidad se aprecia significativamente en algunas localidades repobladas conforme al modelo ensayado en Benavente, cuyo

${ }^{10}$ "Todo omne aqui la honor de Alba dieren, la que pertenece a la real potestat, quando viniere a Alba, en ante que entre enla villa, primero iure sobre sanctos Evangelios en mano de .I. clerigo que a omne o a muler de Alba c de su termino non los saque de fuero ni de carta; e si assi non iurare, nol reciban, e al iucz mol respondan nin le den sus derechuras fasta a iure aquel que quisier recebirlo que pertenece ala real potestat; e si iurare, den sus derechos al iuez ...", Ibidem, cap. 48, p. 311 .

$11 " .$. E estas calonnas si fueren vencidas con quereloso, tome el juez el tercio, e el sennorio tome los dos tercios. E cada anno meta el concexo su iucz", Ibidem, cap. 49, p. 311.

${ }^{12}$ Ibidein, cap. 142, p. 337.

${ }^{13} \mathrm{M}^{\circ} \mathrm{C}$. ASENSIO ARRATIBEL \& R.M*. CADENA VIÑAS, Tenencias de la frontera navarroaragonesa en la segunda mitad del siglo XII, "VII Congreso de Historia de la Corona de Aragón", Barcelona, 1964, pp. 9-14, A. CAÑADA JuSTÉ, Honores y tenencias en la monarquia pamplonesa del siglo X. Precedentes de una institución, "Homenaje a José Maria Lacarra. Anejo 2", Pamplona, 1986, pp. 67-73, C. CORONA BARATECH, Las tenencias en Aragón desde 1034 a 1134, "Estudios de Edad Media de la Corona de Aragón", II, 1945, pp. 379-396, J.M. LACARRA, Honores et tenencias en Aragon $X P^{\text {me }}$ siécle), "Les structures sociales de l'Aquitanie, du Languedoc et de l'Espagne au premier Age Féodal", Paris-Toulouse, 1969, A. UBIETO, Notas sobre los tenentes de Calahorra en los siglos XI y XII, "Principe de Viana", 30 (Pamplona, 1969) y del mismo autor Los tenentes de Aragón y Navarra en los siglos XI y XII, Valencia, 1973.

${ }^{14}$ Esta temática ha sido estudiada por diversos autores, sirvan como ejemplo: I. ÁlvaREZ BORGE, Monarquía feudal y organización territorial. Alfoces y merindades en Castilla (Siglos X-XIV), Madrid, 1993, J. GonzÁleZ, Alfonso IX, Madrid, 1944, pp. 343-361, R. PEREZ BUSTAMANTE, El gobiemo y la adıninistración territorial de Castilla (1230-1474), I, Madrid, 1976, p. 50, F. SAGREDO FERNÁNDEZ, La tenencia de Bureba en la primera mitad del siglo XII, "Homenaje a Fray Justo Pérez de Urbel", I, Silos, 1976, pp. 197-219. 
Fuero se extendió fundamentalmente por la Cornisa Cantábrica y Galicia's, también llegó a núcleos del antiguo reino de León como Mansilla de las Mulas y Laguna de Negrillos, localidades que entraron de lleno en los planes políticos y militares de Fernando II y de Alfonso IX. Ambos monarcas acometieron la reparación y la creación ex novo de importantes bastiones defensivos al calor de los crecientes núcleos urbanos.

Mansilla recibió en torno a 1180 el Fuero de Benavente por concesión de Fernando II, su repoblación se llevó a cabo durante los últimos años del siglo XII y fue la cabeza de una importante tenencia cuyos titulares se conocen con bastante exactitud ${ }^{16}$. El caso de Laguna de Negrillos presenta características similares, su Fuero se conoce a través de una versión tardía de $1480^{17}$. Esta localidad fue entregada en tenencia a los personajes más poderosos de la época coincidiendo con el momento de mayor brillantez del reino leonés. Además, Laguna ocupó un destacado lugar en el fortalecimiento militar de la V ra de la Plata, importante eje viario y principal cauce de expansión para Alfonso IX.

En los Fueros de las Extremaduras la normativa dedicada al dominus villae es considerablemente restrictiva con respecto a sus atribuciones y competencias, y anuncia la definitiva desaparición de este personaje que será sustituído por un concejo fuerte con asentados órganos gubernativos ${ }^{18}$. Así se observa en el Fuero romanceado de Caceres, donde las funciones de este delegado del poder regio sufrieron un considerable detrimento en beneficio de la población ${ }^{19}$. Béjar ofrece una situación semejante donde se deja sentir

${ }^{15}$ A. Garcla Gallo, Los fueros de Benavente, "Anuario de Historia del Derecho Español" (En lo sucesivo "AHDE"), XLI (Madrid, 1971), pp. 1143-1192, J. GonZÁLEZ, El Fuero de Benavente, "Hispania" , IX (Madrid, 1942), pp. 619-626.

${ }^{16}$ Véase VIGNAU, Cartulario del monasterio de Eslonza, Madrid, 1884, Documentos No CIV, pp. 165-167, No CXVIII, pp. 187-188, N ${ }^{\circ}$ CXX, pp. 187-188, N ${ }^{\circ}$ CXXIX, pp. 202-203 y No CXXXI, pp. 205-206.

${ }^{17}$ Este fuero se ha conservado en A(rchivo) G(eneral) (de) S(imancas), R(egistro) G(eneral) (del) S(ello), III-1480, fols. 49-55 y ha sido publicado por J. RODRfGUEZ FERNANDI:Z, Fuero de Laguna de Negrillos, "Archivos Leoneses", 59-60 (León, 1976), pp. 291-316.

${ }^{18}$ F.J. MARTINEZ LLORENTE, Régiinen juridico de la Extremadura castellana medieval. Las comunidades de villa y tierra (S. X-XIV), Universidad de Valladolid, 1990, p. 442.

19 "Nengun senor que toviere a Caceres no meta mano en vizino nee en morador de Caceres que hy morare, fueras el cuerpo del Rey. Et si el ricome querela oviere de algún omne de Caceres, demandelo el manpostero por nuestro fuero et por nuestra carta, et por iudiçio de nuestros alcaldes. Et si ademas quisiere passar, el conceio non lelo consienta", P. LUMBRI:RAS VALENTE, Los Fueros municipales de Cáceres. Su derecho püblico, Cáceres, 1974, ep. 389. p. XC. 
la posición fronteriza de esta localidad, pues el dominus desempeñaba una serie de atribuciones militares y tributarias en las que le asistran el alcaide y el merino respectivamente ${ }^{30}$.

Las dos versiones del Fuero de Sepúlveda muestran claramente la relación existente entre el rey y el concejo que podía ser directa o bien a través de intermediarios: delegados del poder monárquico, potestades y tenentes, monasterios, miembros de la familia real, etc., cada una de estas modalidades marcó una etapa en la evolución del concejo de Sepúlveda. En el Fuero Latino la relación rey-concejo se complica por la presencia del dominus villae que actúa en nombre del $r^{21}{ }^{21}$. Este funcionario se elegía entre los miembros de la corte que ostentaban la dignidad de potestades ${ }^{22}$, y ocupaba un palacio en la villa del que se ausentaba frecuentemente ${ }^{23}$. Como representante de la autoridad monárquica su principal misión consistía en regir Sepúlveda ${ }^{24}$. El Fuero fijaba con minuciosidad los límites de su actuación con el fin de evitar abusos contra la población; además, el concejo le retribuía con los derechos correspondientes. En materia judicial el dominus estaba auxiliado por el juez y quedaba protegido de las posibles prendas que realizasen los vecinos ${ }^{25}$.

Todavía en el siglo XIII el senior representaba el poder del rey en Cuenca ${ }^{26}$; sin embargo, su figura carecía del peso necesario para ejercer una gran influencia ${ }^{27}$. Este personaje ya no intervenfa activamente en las tareas del gobierno urbano ni mantenfa muchas de sus funciones originales como garante del orden y de la paz, lo cual beneficiaba a otros oficiales

\footnotetext{
${ }^{20}$ "Otorgovos que conceio de Beiar non vaya en hueste sinon en su frontera, e con el rey e non con otro, e so el rey; que ayades un sennor e un alcaiat e un merino", J. GUTIERREZ CUAdRAdo, El Fuero de Béjar, Salaınanca, 1975, ep. 21, p. 46.

${ }^{21}$ E. SÁEZ et alii, Los Fueros de Sepúlveda, Segovia, 1953, p. 424.

22 "... si quis ex potestatibus venerit ad regendum ea, ante det sua iantare", Ibidem, F(uero) L(atino), No 33 .

${ }^{23}$ Bbidem, F.L., No 25 .

24 "... illud seniorem qui Sepulvega mandaret ...", Ibidem, F.L., No 27.

${ }^{25}$ Ibidem, pp. 424-425.

26"... e aved deyuso del rrey, un sennor e un alcayde e un merino", R. DE UREÑA Y SMENJAUD, Fuero de Cuenca, Madrid, 1935, cap. I, XVI, p. 123.

${ }^{27}$ "Aquel que judgado o alcaldia por fuerça de alcaldes o de parientes lo quisiere aver o del rrey o de sennor dela villa, o lo vendiere, o fiziere otro perçonnero ante dela jura, non sea juez njn alcalde en todos los dias de su vida, njn tenga ofiçio nin portillo de conçejo", Ibideın, cap. $X V I$, V, p. 427.
} 
concejiles como el juez o los alcaldes ${ }^{23}$; solamente dirigía la hueste ${ }^{29}$ y conservaba cierto prestigio social, ya que cualquier atentado contra su persona se equiparaba al delito de traición del castillo y se castigaha con la muerte por descuartizamiento ${ }^{* 0}$. Asistía al tribunal de justicia todos los días menos el viernes, aunque su presencia parecla ser solamente testimonial ${ }^{31}$; además, el juez se habra convertido en la máxima autoridad en materia judicial, situación que comenzó a ser habitual en los concejos castellanos y leoneses desde finales del siglo $\mathrm{XII}^{32}$. El concejo de Cuenca entregaba voluntariamente al tenente su correspondiente remuneración, ya que "nunca el conçejo de cuenca al rrey njn a otro ninguno njn a otro alguno por fuero njn por derecho, non le a de dar njnguna cosa; ca libre lo fago de toda premja de rrey e de sennor e de todo tributo" ${ }^{33}$.

Conviene recordar que la monarquía no tenía demasiado interés en mantener a estos individuos, más preocupados de percibir las rentas inherentes al cargo que de ejercer un poder efectivo en la ciudad. Por otro lado, el progreso de la autonomia concejil marcó el declive de estos funcionarios regios que terminaron por desaparecer en la segunda mitad del siglo XIII.

\subsection{El alcaide}

Este oticio poseyó a lo largo de todo el período medieval un marcado carácter militar y, a diferencia del dominus villae, sobrevivió e

\footnotetext{
28 "Ninguno nin sennor nin otro non tengan omne preso por calonna en que el palaçio aya parte, sinon el juez tan sola mente: otrosi, nin el sennor non tome al vezino preso, mager que por propia calonna o por debdo sea vençido; mas es juez tengalo preso en su casa, fasta que pague lo que deviere", Ibidem, cap. I, XXII, p. 131.

${ }^{29}$ bidem, cap. XXX, IX, p. 641.

30"... otro si qual quiere que firiere al sennor dela çibdad o lo matare o castillo perdiere, sea partido por miembros", libidem, cap. XI, XV, p. 311.

${ }^{31}$ "El sennor de cuenca enla corte delos alcaldes el dia del viemes non entre e en los otros dias entre quando le ploguiere; pero demjentra el sennor estoviere en la corte non judgue, e si el juez o el alcalde, el sennor seyendo presente, judgare en la corte, peche la demanda al querelloso por la qual fue dado el juyzio; e este es estableçido por que njn, el juez, nin el alcalde por miedo nin verguença del sennor, non judgue tuerto", Ibidem, cap. XXIV, XIX, p. 569. p. 541.

${ }^{32}$ L. GaRcta de Valdeavellano, Curso de Historia de las Instituciones, Op. cit. (nota 6),

${ }^{33}$ R. DE UREÑa Y SMENJAUD, El Fuero de Cuenca, Op. cit. (nota 26), cap. XVI, XII, pp. $431-433$.
} 
incluso alcanzó una gran relevancia social y política en los siglos bajomedievales. Los Fueros otorgados a las Extremaduras y a localidades fronterizas prestan bastante atención a este personaje encargado de defender el alcázar urbano, en ocasiones esbozan algunas normas sobre sus atribuciones luego recogidas por la legislación posterior, pero apenas ofrecen datos sobre la identidad y origen social de las personas que desempeñaron el cargo.

Según el Fuero de Soria la designación del alcaide se realizaba el primer lunes después de la festividad de San Juan. La provisión de este cargo era competencia exclusiva del concejo soriano y el disfrute del mismo era anual, con lo que se pretendía evitar su patrimonialización en manos de una sóla persona. Por otra parte, el alcaide debra pertenecer al grupo de los caballeros $^{34}$, que en la sociedad de la Extremadura castellana ocupo un importante puesto a causa de su principal actividad: la guerra. Esta circunstancia favoreció su posición socio-política y económica en un ámbito en el que la nobleza no logró implantarse hasta mediados del siglo XIV. En otro orden de cosas, conviene señalar que en esta región la estructura territorial vino determinada por la existencia de castillos y plazas fuertes que se convirtieron en cabeceras jurisdiccionales de los distintos núcleos de población. Sin embargo, estos edificios defensivos precisaron una dotación humana adecuada que atendiese a su protección y mantenimiento y que estuvo integrada mayoritariamente por estos individuos ${ }^{35}$. El Fuero de Soria indica asimismo la obligación del alcaide a prestar pleito homenaje por el castillo junto con otros cinco caballeros ${ }^{36}$. Este precepto demuestra que desde el siglo XIII los caballeros villanos podían tomar a su cargo las tenencias de las fortalezas concejiles, aunque el texto no especifica si era necesario que el caballero hubiera de ser a la vez hidalgo ${ }^{37}$. En Sepúlveda

\footnotetext{
${ }^{34}$ "El lunes primero despues de Sant Juan el conçeio ponga cadanno ... un cavallero que tenga a Alcaçar", G. SÁNCHEZ, Fueros castellanos de Soria y Alcalá de Henares, Madrid, 1919, cap. V, ep. 41. Según M. DIAGO, Caballeros e hidalgos en la Extremadura castellana medieval (Siglos XII-XV), "En la España Medieval", 15 (Madrid, 1992), p. 37, nota 17, J. GAUTIER DALCHE identificó errónealmente el Alcaçar del Fuero con el castillo de la ciudad, al parecer este Alcaçar se correspondía con el castillo de Peñalcázar, cuya tenencia proveía el concejo soriano según ha corroborado DIAGO con múltiples referencias documentales, entre otras AGS, C(onsejo) R(eal), 48-1.
}

${ }^{35} \mathrm{M}$. Diago, Caballeros e hidalgos, Op. cit. (nota 34), p. 37.

${ }^{36} \mathrm{G}$. SÁNCHEZ, Fueros castellanos de Soria, Op. cit. (nota 34), cap. IX, ep. 102. 37.

${ }^{37}$ Esta idea ha sido subrayada por M. DIAGO, Caballeros e hidalgos, Op. cit. (nota 34), p. 
el oficio de alcaide recayó en manos de un forastero ${ }^{38}$, y entre sus principales competencias se encontraba la vigilancia y defensa de la fortaleza ${ }^{39}$.

La mayor parte de los textos forales consultados son muy precisos a la hora de limitar las competencias del alcaide, quien tenía la obligación de entregar casa en prendas como garantía del correcto desempeño del oficio y para poder ser recibido por el concejo, en caso de faltar a este deber el juez se haría cargo de la casa y el alcaide no percibirfa su correspondiente remuneració $n^{40}$. Por otro lado, conviene recordar que el alcaide se encontraba subordinado a las órdenes del tenente y ejercia sus funciones cuando éste se ausentaba. Además, en Cuenca participaba en la esculca o guarda del ganado desde el 24 de Junio (festividad de San Juan) hasta el 29 de Septiembre (dra de San Miguel) ${ }^{41}$. Dicha atribución enlaza directamente con la vocación ganadera de esta ciudad fronteriza, donde los contínuos vaivenes bélicos no permitieron otra clase de actividades económicas durante bastante tiempo.

\footnotetext{
38 "Alcayde, neque merino, neque archipresbiter non sit nisi de villa; et iudex [sit de villa et a-Innal et per las collationes; et de cada homicidio accipiat V solidos", E. SÁEZ et alii, Op. cit. (nota 21), F.L., No 24.

${ }^{30}$ Bbidem, F.L., N0 7.

${ }^{40}$ Estas disposiciones se encuentran por igual en los Fueros de Cuenca y Béjar: "... e qual quier que en cuenca oviere de ser alcayade, antes que rrendas rreçiba desta çibdad, de casa con pennos en conçejo, e rreçibala el juez; e si por ventura el alcayade o algun omne de los suyos algun danno o calonna fizieren, el juez prende en aquella casa, fasta que el querelloso aya derecho al fuero de cuenca; e si el alcayade non quisiere dar casa con pennos, el concejo non lo rreçiba", R. DE UREÑA Y SMENJAUD, El Fuero de Cuenca, Op. cit. (nota 26), cap. I, XVIII, p. 125, "Qui ovier a seer alcayat en Beiar dé casa con pennos antes que reciba alguna rendas de la villa, e en conceio reciba al judez", J. GUTIÉRREZ CUADRADO, Op; cit; (nota 20), ep. 23, p. 46, "Sj el alcayat o su omne fiziera algun danno o calonna, pendre el iuez en aquella casa fasta que el querelloso aya derecho a fuero de Beiar. Si el alcayat non quisier dar casa con pennos, el conceio nol reciba ni prenda nada de las rendas de la villa", Ibidem, ep. 24, p. 46.

4"... los sennores delos ganados tengan esculca el mes de diziembre, e de enero, e de febrero, e la meytad de março, dando dos buscos o un cavallo e tres greyes a un cavallero; desde la meytad de março fasta al dia de sant juan, tenga la el conçejo; e desde sant johan fasta al dia de sant miguel, tenga la aquel que fuere alcayad de cuenca, veteta, poveda, almoyonnes, çaforejas, huerta pelayo, canjzares, rrecuenco; estas aldeas den sesenta peones, desde el dia de sant johan fasta el dia de todos santos, que anden en la tierra con los ganados; estas aldeas non tengan esculea con el conçejo, nin pechen en la esculea del conçejo; e el cavallero que toviere de çient ovejas arriba, tenga esculca; e asi commo cada uno echare las ovejas por sant johan, asi sea por todo el anno; e quien esto non fiziere montenle las ovejas; e el cavallero que en eaculca fuere, tenga cavallo que vala de veynte mr. arriba, si quier sea de la çibdad e si quier del aldea", R. DE UREÑA Y SMENJAUD, El Fuero de Cuenca, Op. cit. (nota 26), cap. XXXIX, III, p. 763.
} 


\subsection{El "palatium"}

El palatium representaba en los concejos castellanos y leoneses el poder del monarca en un sentido material y simbolico. Numerosos preceptos del Fuero de Cuenca se refieren a esta entidad que constituyó el máximo organo de poder en la organización jurídica y política del concejo ${ }^{42}$. El vocablo palatium incluye significados de variados ordenes referidos a realidad material, a unidad de explotación agraria, a centro perceptor do rentas, a centro de ejercicio de la justicia y a realidad simbólica en el juego de la dominación social ${ }^{43}$. En los textos municipales contemporáneos del Fuero de Cuenca aparece como un organismo encargado de recaudar diversas penas judiciales o como el beneficiario de los bienes de los fallecidos sin parientes próximos ${ }^{44}$.

El palacio posera también una plasmación concreta en una serie de edificaciones; asi, en los Fueros de Cuenca y de Cáceres se contempla la existencia de dos palacios en la ciudad: el real, más conocido como alcázar, y el episcopal ${ }^{45}$. Ya fuera en su dimensión material o jurídica esta entidad simbolizó la presencia monárquica en la ciudad y por tanto el elemento que mejor definía su autoridad con facultad para juzgar y para percibir las multas impuestas a los infractores de las normas. Sin embargo, el palatium fue perdiendo vigor al compás del fortalecimiento del poder monárquico, que ya no necesitaba de intermediarios para ejercer su primacía en los núcleos urbanos, pues el rey intervenfa de forma más o menos directa en el nombramiento de magistrados, instalaba agentes financieros que dependian

\footnotetext{
${ }^{42}$ Véanse en especial cap. I, XIX-XXI, pp. 125-129, cap. IX, VIII-XIV, pp. 253 y 257, cap. XXII, IX, p. 531.

${ }^{43}$ J.A. GARCIA DE CORTÁzAR \& E. PEÑA BOCo, El palatium, símbolo y centro de poder en los reinos de Navarra y Castilla en los siglos X A XII, "Mayurqa. Homenaje al Profesor don Álvaro Santamaría", I, (Palma de Mallorea, 1989), p. 283. Véase también J. FACI, Vocablos referentes al sector agrario en León y Castilla durante la Alia Edad Media, "Moneda y Crédito", 144 (Madrid, 1978), pp. 86-87.

${ }^{4}$ Esta idea ha sido recientemente subrayada por C.M". REGLERO DE LA FUENTE, Los señorios de los Montes Torozos. De la repoblación al Becerro de las Behetrias (Siglos X-XIV), Valladolid, 1993, pp. 32-33.

45"... por la qual cosa mando, que en cuenca non ayan mas de dos palaçios atan sola mentre el del rrey e el del obispo; todas las otras casas asi del pobre commo del rrico, asi del noble commo del non noble, un fuero ayan e una calonna", R. DE UREÑA Y SMENJAUD, El Fuero de Cuenca, Op. cit. (nota 26), cap. I, VIII, p. 119, "Qua propter mando quod in tota Caceres non habeant nisi duo Palacie tantum, Regis silicet (sic) et Episcopi ...", P. LUMBRERAS VALENTE, Op. cit. (nota 19), p. V.
} 
directamente de él y su tribunal se ocupaba exclusivamente de las apelaciones de las jurisdicciones ciudadanas. Por otro lado, el crecimiento de la autonomía concejil y el desarrollo de los órganos gubernativoss del municipio influyeron decisivamente en este proceso de debilitamiento, hasta el punto de que a mediados del siglo XIII el palacio servía solamente como morada al rey ${ }^{46}$.

\section{LAS FORTIFICACIONES: CUIDADO Y MANTENIMIENTO DE LOS ELEMENTOS DEFENSIVOS}

La reparación y conservación de los elementos fortificados fue una de las principales preocupaciones de los concejos castellano-leoneses durante toda la Edad Media, esta realidad se hizo más patente en aquellas ciudades donde las fortificaciones exigieron mayores cuidados a causa de una actividad militar más continuada. Los fueros de la época se hicieron eco de estas necesidades y dedicaron numerosos preceptos a regular esta cuestión ofreciendo una normativa muy rica y variada.

El Fuero de León en su norma XXVIII fijaba los límites del alfoz de la ciudad y obligaba a los habitantes de este territorio y a los de la villa a participar en tiempo de guerra en la reparacion y vigilancia de sus murallas, a cambio quedaban exentos de pagar el portazgo por los productos que trajesen a vender en el mercado ${ }^{47}$. Esta equiparación entre los moradores de León y los de su alfoz obedecía al deseo de reforzar la defensa de la ciudad en momentos críticos, pues al fin y al cabo unos y otros se beneficiaban de la protección que brindaban los recios muros leoneses ${ }^{48}$. Por otra parte, las murallas no sólo definieron el espacio urbano en su dimensión

\footnotetext{
${ }^{46}$ F.J. MARTINEZ LLORENTE, Régimen juridico de la Extreinadura castellana medieval, Op. cit. (nota 18), p. 441.

47" et in tempore belli et guerra, veniant ad Legionem vigilare illos muros civitatis, et restaurare illos, sicut cives Legiones, et non dent portaticum de omnibus causis quas ibi vendierint", J. RODRIGUEZ FERNÁNDEZ, Los Fueros del Reino de León, León, 1981, p. 96.

${ }^{48}$ En eate sentido conviene recordar el efecto devastador que provocaron las incursiones de Almanzor en estas tierras. Las murallas de León y las de Astorga fueron parcialmente arrasadas y los núcleos urbanos y sus alrededores quedaron totalmente desprotegidos ante al peligro musulmán.
} 
militar, también bajo su amparo creció un floreciente mercado al igual que ocurriría en otras ciudades castellanas y leonesas".

En otros textos forales otorgados a diversas localidades del reino de León abundan las disposiciones relativas a la reparación y construcción de muros, lo que coincide con la destacada posición fronteriza que ocuparon muchas de ellas. En Salamanca la defensa de la ciudad dependía de la existencia de dos muros: uno que rodeaba la ciudad y otro que protegía el arrabal $^{50}$, para la construcción de ambos se precisaba la ayuda de todos los vecinos bajo pena de $100 \mathrm{mrs}$. de multa ${ }^{51}$. Por otro lado, los clérigos estaban excusados de pagar cualquier pecho, labor de castillo o fazendera, ya que pertenecían a la jurisdicción eclesiástica. Especial consideración merece el precepto que contemplaba la posibilidad de invertir una parte o la totalidad de los bienes del difunto en la edificación de iglesias, puentes o murallas, para evitar malversaciones y abusos se instaba a los alcaldes y justicias a cumplir estas últimas voluntades ${ }^{52}$. Al igual que en otros Fueros extensos, en el de Salamanca se fijaron ciertas multas judiciales o calonas cuya cuantía se destinó a la reconstrucción de las defensas urbanas ${ }^{53}$; incluso, se creo un impuesto especial denominado el mortorio del muro cuya recaudación se empleo en las obras de la muralla ${ }^{54}$.

Ledesma ocupó un lugar estratégico en la frontera con el vecino reino de Portugal durante toda la Edad Media, esta circunstancia influyó notablemente en el Fuero otorgado en la segunda mitad del siglo XII, donde

\footnotetext{
${ }^{49}$ Sobre la relación entre el mercado leonés y las murallas véase L. GARCla DE VALDEAVELUANO, El mercado. Apuntes para su estudio en León y Castilla durante la Edad Media, "AHDE", VIII (Madrid 1931), pp. 201 403, J. RODRIGUEZ FERNÁNDEZ, Situación del mercado leonés. Siglos X-XI, "Archivos Leoneses", 10 (León, 1957), C, SÁNCHEZ ALBORNOZ, Una ciudad de la Esparia cristiana hace mil arios, Madrid, 1988, 12 " ed.

so" Esta salud vieron los alcaldes que eran en Salamanca quando el Emperador fue Almaria: que fagan el muro; e quando fuer fecho el muro dela cipdade, fagamos otro muro ena arravalde, poro viren, por bien alcaldes e iurados de conceio", A. CASTRO \& F. DE ONIS, Op. cit. (nota 7), cap. 159, p. 135 .

sl"Et elos dela cipdade affien alos dela arravalde, que quando fecho fuer el muro dela cipdade, quales aiuden afazer el muro dela arravalde; e [si] elos omnes que los alcaldes vieren por bien por este servicio façer, non quisieren hy seer, peche .C. moravedis cada uno delos, e entren en el servicio", Ibidem, cap. 160, p. 136.

${ }^{52}$ Ibidein, cap. 220, p. 156.

${ }^{33}$ Así, la viuda que casase antes del año pagaría 2 mrs. que se emplearian en la lavor del muro y perdería la manda testamentaria, Ibidem, cap. 213, p. 155.

s4"Todo omne que moriere e ovier valia de .XX. moravedis, de .I. moravedi al muro; e de .X. moravedis, medio ...", Ibidem, cap. 294, p. 185.
} 
aparece un nutrido grupo de normas dedicadas principalmente al cuidado y mantenimiento de las fortificaciones. La mayor parte de estos preceptos se refieren a penas judiciales que se invertían en las obras de los muros ${ }^{55}$. En ocasiones, la cuantia de estas calonas era bastante elevada: 20 mrs. en los casos de mentira o perjurio ${ }^{56}, 30 \mathrm{mrs}$. cuando no se satisfacía en el plazo convenido el importe de una compra-venta ${ }^{57}$ y la misma cantidad en las demandas $^{38}$. Como puede comprobarse, estas multas se correspondían siempre con delitos graves de orden penal (deshonra de la mujer) y privado (compra-venta de heredades).

También Alba de Tormes surgió como enclave fronterizo y conoció varias fases de repoblación, esta similitud con Ledesma se aprecia igualmente en el Fuero, que prestó una atención primordial a la reparación de los elementos defensivos a juzgar por el número de caloñas que se destinaron a este asunto y por su elevada cuantía ${ }^{59}$. La edificación de construcciones militares se limito en Alba a la torre de la iglesia y al castillo, la infracción de esta norma conllevaba una sanción de $100 \mathrm{mrs}$. a repartir entre el juez, los alcaldes y el denunciante, así como la destrucción total de la obra. Con esta restricción se pretendía evitar la proliferación de otros puntos fuertes en la villa que pudiesen originar conflictos y convertirse en refugio de malhechores y criminales ${ }^{60}$.

Ss". .. E si conceyo sobier verdat que andadores o sayon moravi dier alguno por andadurja, cayales en periuro; e quanto dieren, en prol de muro e dela puente ...", lbidem, cap. 157, p. 244, "Toda mugier ayena de beneyçion, quien aella dier salto en carrera o en qual lugar fur, e la fodir, ..., prendanno alcallde e conceyo e enforquenllo, commo alevoso e traydor, e pierda quanto ovier. E esse aver quelle axaren, las dos partes entren en prol de conceyo e de la puente e del muro, e la tercja a los alcaldes", Ibidem, cap. 190, p. 249.

56"Todo omne que mentira sabida iurar o firmar ondelo [s] alcalldes e las iusticias sobieren verdade, peche .XX. moravis sea falso e nunca sea coyecho en iura nin enfirma nen entestimonja e esos moravis metalos el conceyo en provecho del muro o dela puente", Ibidein, cap. 267, p. 263.

57 "Todo omne que su heredade propia vendir e despues la demandar, de fiador quese la non podier vençer, que peche .XXX. moravis pora el casticllo e .X. moravis pora elque tovier ela heredade; e de mugier, otrosi", Ibidem, cap. 377, p. 282.

s8" Si fijo demandar heredade que padre o madre vendieren, e elle demandare, si firmarlelo podieren, peche .XXX. moravis pora el castiello e .X. moravis pora el que pierde ela heredade", lbidem, cap. 379, p. 283.

${ }^{50}$ Véanse en particular cap. 114 , p. 331 , cap. 129, p. 334 , cap. 145 y 146, p. 338.

conenguno omne non faga torre si non fuere en ecclesia o en castiello. Todo omne o muler de Alba o de su termino que omne o muler de Alba o de su termino matare, e en ecclesia o en la torre de la eglesia se encerrare, sus parientes del muerto tomen las laves dela eglesia e dela torre, e guarden lo si se quisieren fasta que isca el mal fechor; e si saliere el mal fechor e lo 
Los progresos de la arquitectura militar surgidos a partir del siglo XII se manifestaron en la edificación de nuevos recintos amurallados y fortificaciones que precisaron una defensa mejor organizada y más eficaz. El Fuero de Cuenca y otros afines a este texto aportaron una solución jurídica adaptada a las nuevas necesidades castrenses. De este modo nacio la figura del vela o vigía, cuyo desfallecimiento se penaba gravemente; también se dieron algunas disposiciones orientadas a la defensa de las torres albarranas y las corachas que se añadieron a las murallas ya existentes ${ }^{61}$. Cuenca, Consuegra, Alcaraz, Alarcón y otras localidades próximas conservan todavía en su fisonomía actual las huellas de su pasado como villas fuertes del reino, al igual que sucede en ciudades extremeñas como Cáceres, Badajoz o Plasencia ${ }^{62}$.

El Fuero de Cuenca es uno de los más característicos de toda la Edad Media castellana, tanto por su contenido como por su expansión a otros puntos de la geografía peninsular. Este texto posee un marcado sentido militar, nota común a otros fueros municipales de la época. Su normativa recoge, en opinión de Salvador de Moxó, la articulación del primitivo Derecho Militar ${ }^{63}$, ya que desarrolla con gran amplitud y precisión una

pudieren tomar, a duganlo e denlo alos alcaldes; e los alcalldes fagan del iusticia, e de su aver non pierda nada. Si alguno amparar las laves de la eglesia o dela torre, aquel que las ampara, de el mal fechor aderecho; e si non lo diere aderecho; e el muerto fuere postero o post[er]a peche .CCC. moravedis; e si non fuere postero nin postera, peche .XXX. moravedis; e si fuere valadi, peche .XX. moravedis. El que fiziere torre, si non fuere en eglesia o en castiello assi como es dicho, peche .C. moravedis e vala menos por elo; e si, desfagala; e si non la desatar el conceio desatela sin calonnia; e desta calonnia tomen los alcalles el tercio, e el iuez el tercio, e el tercio el quercloso; e por esto nenguno non se alce ala real potestat", A. CASTRO \& F. DE ONIs, Op. cit. (nota 7), cap. 42, pp. 309-310.

${ }^{61}$ Sobre este particular véanse F. BORDEJE, Las fortalezas musulmanas españolas, "Boletín de la Asociación Española de Amigos de los Castillos" (en lo sucesivo "BAEAC"), II (Madrid, 1954), M. CASTAÑOS, Corachas, torres albarranas y baluartes, "Arte Español", IV (Madrid, 1918-1919), del mismo autor Almenas, merlones y matacanes, "Toledo", (Toledo, 1923), A. DOTOR, Los castillos árabes en Esparia, "BAEAC", XII (Madrid, 1964), A. NAVAREÑo MATEOS, El castillo bajomedieval: arquitectura y táctica militar, "Las armas en la Historia. Gladius", 1988, pp. 113-152, H. TERRASSE, Les forteresses de l'Espagne musulmane, Madrid, 1954, L. TORRES BALBAS, Las torres albarranas, "Al-Andalus", VII (Madrid, 1942), pp. 216219, del mismo autor Los contomos de las ciudades hispano-musulinanas, "Al-Andalus", XI (Madrid, 1946), pp. 437-486, Atarazanas hispano-musulmanas, "Al-Andalus", XV, (Madrid, 1950), pp. 175-210, Barbacanas, "Al-Andalus", XVI (Madrid, 1951), Las puertas en recodo de la arquitectura militar hispano-musulmana, "Al-Andalus", XXV (Madrid, 1960).

${ }^{62}$ Sobre estas últimas véase L. TORRES BALBÁs, La alcazaba alınohade de Badajoz, "AlAndalus", VI (Madrid, 1941), pp. 163-203, Cáceres y su cerca alınohade, "Al-Andalus", XIII (Madrid, 1948), pp. 446-472.

${ }^{63}$ S. DE MOXO, El Derecho Militar, Op. cit. (nota 2), p. 14. 
serie de disposiciones en las que se basaba el régimen militar de las ciudades castellanas fronterizas, algunas de las cuales poseyeron este carácter durante bastante tiempo. Así, todos los habitantes y vecinos conquenses tenfan la obligación de contribuir a la reparación de los muros, adarves y atalayas de la ciudad y su término mediante una prestación personal denominada castellaje. Tan sólo quedaban excusados de este deber los caballeros cuya cabalgadura valiese más de 50 mencales ${ }^{\text {th }}$.

La caballería de Cuenca desempeñó un papel de gran trascendencia en el control del gobierno urbano al ir desplazando progresivamente a los boni homines. Con el tiempo, los caballeros se organizaron en linajes y recibieron el apoyo de la monarquía frente a los mercaderes y artesanos, que empezaron a despuntar en el tránsito del siglo XII al XIII. En Cuenca, la caballería popular constituyó la cofradía de los guisados o armados de caballo, en clara consonancia con su vocación militar. Aunque estos individuos no poseran estatuto de nobleza lograban equipararse a ésta por medio de la obtención de ciertos privilegios y exenciones derivados del mantenimiento de caballo y armas con carácter permanente ${ }^{65}$. Un fenómeno de semejante naturaleza se observa en Toledo, donde el privilegio otorgado en 1174 establecía que los campesinos que entregasen la décima parte de sus cosechas de cereal y de vino al fisco regio quedarian exentos de "servicium faciendum super bestias illorum, non serna, non fosateria, nec vigilia in civitate nec in Castello, sed sint honorati et liberati, et ab omnibus laceribus imperati et quisquis ex illis equitare voluerit, in aliquibus temporibus equitet, et intret in mores militum" acomodados resultarían muy favorecidos, pues se les permitf́a abandonar el arado por la profesión del caballo y las armas, surgiendo de este modo una caballería villana que adoptó actitudes y formas de vida parecidas a las de los caballeros hidalgos.

\footnotetext{
An Qual quier que tovjese en la çibdad casa e sila toviese poblada, sea quito de todo trjbuto, asi que non peche en ninguna otra cosa, sinon enlos adarves dela çibdad e enlas torres del vuestro termino: pero el cavallero que toviere en su casa cavallo que vala de çincuenta mencales arriba e [casa] en la çibdad, non peche en los adarves, nin en las otras cosas por sienpre", R. DE URENA Y SMENJAUd, El Fuero de Cuenca, Op; cit; (nota 26), cap. I, VI, p. 119.

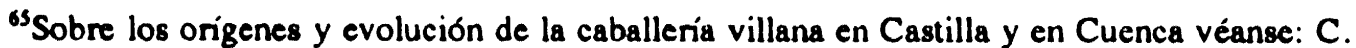
PESCADOR, La caballería popular en León y Castilla. "CHE", 33-40 (Madrid, 1961-1964), pp. 101-238, 56-201, 88-198 y 179-260, M`D. CABAÑAS GONZÁLEZ, La caballeria popular en Cuenca, Cuenca, 1980.

${ }^{\circ} \mathrm{T}$. MUÑOZ Y ROMERO, Colección de fueros municipales y cartas pueblas de los reinos de Castilla, León, Corona de Aragón y Navarra, Madrid, 1970, p. 381.
} 
La conservación y mantenimiento de las murallas y elementos defensivos aparece perfectamente regulada en el Fuero de Cuenca. Además, se ofrecen algunos datos interesantes acerca de la organización y desarrollo de estas obras de reparación. Los artesanos y maestros constructores realizaban su trabajo conforme a unos plazos previamente acordados, el incumplimiento de los mismos acarreaba una serie de severas sanciones, ya que la seguridad de la villa y de sus habitantes dependía del buen estado de las fortificaciones ${ }^{67}$. El texto proporciona algunos detalles sobre la existencia de terrenos próximos a Cuenca de los que se extrafan los materiales de construcción necesarios para la reparación de los muros: molar (terreno calizo) y tejar (materia arcillosa apta para la fabricación de adobes, tejas y ladrillos), prohibiéndose su enajenación a favor del concejo o de particulares $^{68}$.

Algunas penas pecuniarias se invirtieron en la restauración de las defensas conquenses, fenomeno que también se ha registrado en los fueros de otras localidades. El concejo tenía la obligación de gestionar la recaudación de estas calonas y de invertirlas en pro de la conservación y reparación de los muros; así ocurrio con las dos terceras partes de las multas del almotacén ${ }^{69}$, y con la mitad de los bienes del que pescara sin anzuelo en el río Júcar ${ }^{70}$ o del que quebrantase las treguas del concejo ${ }^{71}$.

En los Fueros de las Extremaduras la conservación de las fortificaciones y defensas urbanas ocupó un lugar preferente, tal y como se observa en el Fuero Latino de Cáceres, que coincide con el de Cuenca en la exención

67" Si el maestro alguna obra començare commo torre, o iglesia, o libro, o puente, o casa, o molino, o vinna, o qual quier otra obra, acabela segun el pleito oviere puesto; si non, peche el aver que oviere rreçebido doblado, ...", R. DE UREÑA Y SMENJAUD, El Fuero de Cuenca, Op. cit. (nota 26), cap. XLII, I, p. 793.

os" Otrosi mando que el arenal e el molar, e el tejar que lo non compre njnguno para los adarves, njn el conçejo conpre aquella eredad do estas cosas fueren falladas, e esto sea por sienpre guardado", lbidem, cap. XLIII, IV, p. 815.

69" ... e esta calonna que sea partida en tres partes, la una terçera parte partala el almotaçen con el querelloso, e las dos que fincan sean del conçejo, para çerrar los forados dela çibdad", lbidem, cap. XVI, XXXIII, p. 449.

${ }^{10}$ "Qual quier que desde la foç de villalva con algun engenno pescare, salvo con anzuelo, fasta belvis, prendenlo e pierda lo que ovierc; la meytad sea para la obra delos adarves e la otra meytad para guardar los montes e las aguas...", Ibidem, cap. XLIII, XIII, p. 821.

71 "Qual quier que quebrantare la tregua del rrey o del conçejo, despennenlo, si fuese preso; e si escapare, que quiere que aya mueble o rrayz pierda lo e pongalo en la lavor delos adarves", Ibidem, cap. XLIII, X, p. 819. 
perpetua de castellaje para los caballeros que acudiesen a poblar la villa ${ }^{72}$. Este tipo de privilegios sirvió como revulsivo para atraer a la población hacia las tierras recién conquistadas, y permitió a los caballeros constituirse como un grupo socialmente privilegiado y como una élite de poder dentro de los concejos de las Extremaduras. Según el Fuero Romanceado de Caceres, las obras de reparación de la muralla se convirtieron en uno de los principales cuidados del concejo, pues se destino el importe de ciertas calonas para hacer frente a los gastos que originaban ${ }^{73}$. En cuanto a la realización de los trabajos, el Fuero fija con precisión la época en que se debran realizar, los materiales a utilizar y la obligación que tenía el concejo de proporcionarlos ${ }^{74}$.

Usagre y Coria presentan importantes coincidencias con Cáceres en el cuidado y mantenimiento de las construcciones defensivas. Así, la primera de estas localidades perteneció a la Orden de Calatrava y recibió su Fuero en el siglo XIII, el cual prevee la inversión de determinadas penas judiciales en la reparación del castillo ${ }^{75}$ y la realización de las obras con arreglo al mismo estatuto que en Cáceres ${ }^{76}$. Asimismo, en Coria se emplearon las cantidades procedentes de numerosas calonas en la reparación de la fortaleza $^{n}$, al igual que los bienes del que participase y promoviese los

\footnotetext{
${ }^{n}$ "Cavallarius etiam, qui equum valentem quindecim morabetinos auto amplius in domo sua in villa tenuerit, et non atafarratum non pectet, neque in murus neque in turribus neque in ullis causis imperpetuum", P. LUMBrerAS VALJENTE, Op. cil. (nota 19), p. V.

73"Todo omne de Caceres que dixerit a otro que es traidor del conceio o del Rey, sepan verdad alcaldes et bonos omes, et si sopieren verdad que traydor es, faganle del cuerpo iusticia, et metan el aver en el castiello", Ibidein, ep. 390, p. XCl, "Todo omne de Caccres que parare con el senor por dano del conceio, vizino nin morador, cxea por aleuso del Rey et del conceio, et tome el conceio so aver, et metanlo en el casticlo", Ibidein, ep. 391, p. XCl.

74 "Los lavradores del castiello fagan su lavor usque ad festum Sancti Martini, si cal ovieren a farto. Et lo que ficare del marco que les diere el conceio o que sacaren d'almoneda, faganlo doblado", Ibidem, ep. 256, p. LXVI.

${ }^{75}$ "Tod omne que en calle, o en castiello, o en carrera o en carcava iectare estiencol ... pectec .I. moraveti a conceio. Otrosi, qui cavare tierra o arena sol castiello, pectet .I. moravedi al conceio, et fagalo dargamasa", R. DE URENA Y SMENJAUD \& A. BONILLA SAN MARTIN, Fuero de Usagre, Madrid, 1907, cap. 163.

${ }^{76}$ Bbidem, p. 262.

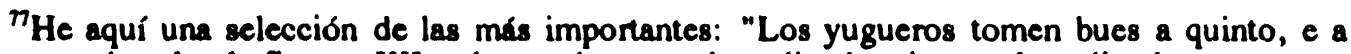
cada uno den dos kafiçes e IIIl ochavas de pan, el medio de trigo e el medio de çenteno, e media ochava de sal e IIII pares de abarcas buenas. E qui mas diere ho mas pidiere, peche IIII maravedis al castiello ..." , J. MALDONADO Y FERNÁNDEZ DEL. TORCO, El Fuero de Coria. Estudio histórico-juridico, Madrid, 1943, ep. 107, p. 40, "... E si peores clavos o peores herraduras hizieren, peche cada uno IIII maravedis al casticllo ...", Ibideln, ep. 111, p. 41, "Ovejas que paçieren entre aldeas, anden çiento en uno e non mas, e çinquenta vacas e no mas.
} 
bandos en la villa ${ }^{78}$, los del traidor $^{79}$ y las tres cuartas partes del patrimonio del que sacase las cosas vedadas a tierra de moros ${ }^{\mathbf{\infty}}$; finalmente, conviene recordar que las obras se ejecutaban siguiendo el mismo sistema que en Cáceres ${ }^{81}$.

Como es bien sabido, esta continua preocupación por la conservación de las fortificaciones coincide con la importancia que éstas adquirieron en la Extremadura leonesa, sujeta a continuas luchas fronterizas entre almohades, leoneses y portugueses. De hecho, este fue el sector más atentido en construcciones militares por los almohades, que prefirieron erigir en la Península edificios defensivos con un marcado carácter castrense para poder acantonar ejércitos que garantizasen una defensa eficaz ante los numerosos ataques de los castellanos y de los leoneses, mientras que en el territorio marroqui sus construcciones defensivas se guiaron esencialmente por la estética ${ }^{\text {2 }}$.

Béjar y Plasencia se enmarcan dentro de esta misma realidad, pues ambas localidades crecieron al calor de los acontecimientos políticos y militares del siglo XII. La protección de la frontera castellana frente al vecino reino leonés y la necesidad de conjurar el peligro musulmán en un

E si mas y andodieren, pechen un maravedi al castiello cada domingo", lbidem, ep. 150, p. 52 , "Los yunteros tengan las yuntas de las alcaldias de las hernandades e tomen su cevada, e sus viudas, e sus treguas; e si mas tomaren, sean perjurados e ixcan del portiello. E non tomen ningun preçio. E todas treguas son quatro maravedis. E si a los VI viniere pesquisa, que por otro juizio aver tomaron, scan perjuros e ixcan del portiello o pechen $\mathrm{XX}$ maravedis al castiello", lbidem, ep. 266, p. 78, "... E si sacare ende ome del çepo, pague çien maravedis, la meatad al castiello, e la otra meatad a los alcaldes e a los seis ...", Ibidem, ep. 332, p. 92, "Los alcaldes no esten en corral con los seis, sinon quando enbiaren por ellos. E si los seis vieren cosa ende se devan partir los alcaldes, diganles que se partan ende. E si non se quisieren partir ende, sean perjuros e pechen çien maravedis al castiello", Ibidem, ep. 351, p. 96.

${ }^{78}$ "A esto el conçejo avenido, que nengun ome de Coria que vando hiziere ho a vando se llamare, sino al cuerpo del rey, saquenlo por alevoso del rey e del conçejo, e derribenle las casas, e pierda quanto ovier, e tomenlo los omes del conçejo e metanlo en el castiello", Ibidem, ep. 6, p. 15.

${ }^{79}$ "Todo ome de Coria que dixieren ques traidor de conçeio o de rey, enquiran alcaldes e bonos omes; e si fallaren ques traidor fagan del cuerpo justiçia e metan el aver en el castiello", lbidem, ep. 140, p. 49.

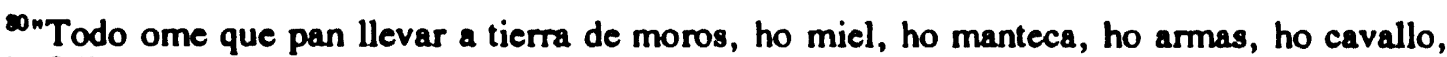
qui lo fallar tomelle quanto truxier sin calonna, e aduga el cuerpo a los alcaldes, e fagan delle justiçia, e pierda quanto ovier. E los alcaldes tomen el quarto, e las tres partes metan en el castiello. E si dixier 'no lo pu(e)de prender', salvese con IIII vezinos", Ibideın, ep. 234, p. 71.

"lbidem, ep. 255, p. 76.

"Sobre esta cuestión véase: MARÇAIS, L'architecture musulınane d'Occident, Paris, 1954 y H. TERRASSE, Les forieresses, Op. cit. (nota 61). 
momento de debilidad política del monarca Alfonso VIII, contribuyeron decisivamente al fortalecimiento de este sector de la Extremadura leonesa, donde se adivina un fuerte influjo de Ávila y Cuenca en los textos forales otorgados a estas tierras ${ }^{\mathfrak{n}}$. Como ya venía siendo habitual en otros concejos extremenos, los vecinos estaban excusados de pagar todo tributo o pecho, salvo de reparar los muros y castillos de la villa, tan sólo los caballeros se libraron de esta carga ${ }^{\mu}$. Las murallas de Bejar adquirieron una especial significación a través del Fuero, pues se convirtieron en punto de referencia para posibles delitos derivados de la práctica de diversiones peligrosas como el bohordo o lanzamiento de armas arrojadizas, de juegos con el caballo y el escudo, as como de otros frecuentes en bodas y fiestas ${ }^{85}$.

Los fueros municipales estudiados desvelan la preocupación de los concejos castellanos y leoneses por mantener en buen estado las fortificaciones y defensas urbanas, que en ocasiones generaron gastos muy gravosos para la fiscalidad municipal, siempre necesitada de recursos. Esta situación se prolongo durante toda la Baja Edad Media; sin embargo, las cantidades recaudadas a partir de las multas judiciales fueron insuficientes $\mathrm{y}$, a menudo, se requirió la ayuda de la Corona para subvencionar la lavor de los muros. Por otro lado, durante los siglos XIV y XV, junto a las obras de reparación de murallas y alcázares, se construyeron nuevos edificios defensivos y se demolieron otros que habran quedado totalmente obsoletos, estas iniciativas tuvieron una plasmación muy concreta en la documentación de la época, lo que ha facilitado un estudio más profundo de esta cuestión ${ }^{86}$.

\footnotetext{
${ }^{83}$ Sobre la compleja realidad histórica de estas tierras véanse los excelentes trabajos de E.C. DE SANTOS CANALEJo sobre El Siglo XV en Plasencia y su tierra. Proyección de un pasado y reflejo de una época, Cáceres, 1981 y La Historia medieval de Plasencia y su entomo geohistórico: La Sierra de Béjar y la Sierra de Gredos, Cáceres, 1986.

4j. GuTIÉRREZ CuADRADO, Op. cit. (nota 20), epgrfs. 8 y 9, p. 44.

ss"Mando que ninguno non peche omezillo nin callonna por omne que mataren o firieren en bofordo de conçeio, o en depuerto, o en iuego de bodas, o de empellada de cavallo, o con escudo o con asta, o por otra manera, fueras de los muros de la villa. Cassi dentro los muros bofordare algui, e omne firiere o matare, peche la callonna e el danno que fiziere", lbidem, ep. 287, p. 81.

*Sirvan como ejemplo, entre otros, los trabajos de M.A. LADERo QUESADA, Les fortifications urbaines en Castille aux $\mathrm{X}^{+m}-\mathrm{XV}^{\mathrm{m}}$ siécles: Probléınatique, financement, aspects sociaux, "Fortifications, portes de villes, places publiques, dans le monde mediterranéen", Ed. J. Heers, Paris-Sortonne, 8.a., pp. 145-176, y de $M^{*} \mathrm{C}$. QuINTANILLA RASO, La ciudcid de Huete y su fortaleza a fines de la Edad Media. A proposito de una reconstrucción en tiempo de los Reyes Católicos, Cuenca, 1991.
} 


\section{LA ORgANIZACIÓN MILTTAR DE LOS CONCEJOS Y SU PARTICIPACIÓN EN LAS ACTIVIDADES BÉLICAS}

Los concejos castellanos y leoneses de los siglos XI al XIII desarrollaron y perfeccionaron considerablemente su organización militar gracias a la instalación de nuevos dispositivos de vigilancia y defensa, surgidos a consecuencia de las mejoras introducidas en el campo de la arquitectura castrense; pero, además, aquéllos intervinieron activamente en la defensa del territorio a través de otros mecanismos no menos eficaces, entre los que conviene destacar las milicias concejiles ${ }^{87}$, que gozaron de gran relevancia en las Extremaduras. Por tanto, puede afirmarse que en los fueros estudiados se ofrece una reglamentación muy novedosa sobre ambos aspectos.

En Zamora se requería la participación directa de los vecinos en la vigilancia de las puertas de la villa durante la semana; asimismo, se estipulaban las prendas y caloñas que debran satisfacerse en caso de faltar a este deber ${ }^{88}$. Un precepto similar se encuentra en el Fuero de Cuenca, donde el cuidado y defensa de las murallas y puertas de la ciudad se encomendó en tiempos de guerra a un grupo de vecinos escogidos en cada collació $^{89}$, en Béjar recibieron la denominación de velas y guardas ${ }^{90}$,

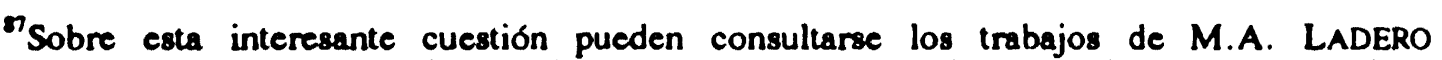
QUESADA, La organización militar de la Corona de Castilla en la Baja Edad Media, "Castillos medievales del reino de León", Madrid, 1989, E. LOURJE, A Society organized for War: Medieval Spain, "Past \& Present", 35 (Oxford, 1966), pp. 54-76, J.F. POWERS, A Society organized for War. The Iberian Municipal Militias in the Central Middle Ages, 1000-1284, University of Califomia Press, 1988.

a"Home que puerta fur monir con bonos hommes una vez la vaya monir por toda la semana; e téngala abierta hasta la hora de la terçia, e desd'í cierre sua porta sin caloña. E se non fur prindar otro dia el que mune la puerta hasta la tercia, e el que tovier la puerta monida hobier quexume del que la puerta mune, vaya (a) prindalo desde que pasare la hora de la tercia; e cual d'ellos quier que prinde primero por esa prinde hayan ambos derecho. E aquel por que fincare derecho, se tovier, prindalo, suelte la prinda; e se soltar non quisier prindar, tuélganle prinda sin caloña, e el otro prinde cada dia hata que haya so derecho", J. MAJADA NELA, El Fuero de Zamora. Introducción. Transcripción. Vocabulario, Salamanca, 1983.

${ }^{90}$ R. DE URENAA Y SMENJAUD, El Fuero de Cuenca, Op. cit. (nota 26), cap. XXX, I, pp. 635-637.

${ }^{90}$ "Quando el conçeio ovier a yr en hueste, ante que yxca, ponga velas e guardas de cada collacion que velen e guarden la villa, e finquen dos alcaldes iurados con el iudez fechizo, qual el iudez annal delexare en su lugar. Estos alcaldes con el iudez fagan curiar la villa como es dicho ... Si por ventura, lo que Dios non mande, que si alguna cosa sencendiere, todos vayan a primas e apriessa a las puertas de la villa e cierrenlas; e desende tomense al fuego amatar ... ca muchas veces conteçio que algunos que quieren traer la villa encendieron alguna cosa, que
} 
éstos percibran como pago a los servicios prestados una caballería de la hueste, con lo que se pretendía disminuir la presión tributaria sobre el resto de los vecinos ${ }^{\text {91 }}$.

Las principales innovaciones en materia de vigilancia se incorporan en el Fuero de Teruel' ${ }^{2}$, donde aparece la figura del centinela, fenómeno que guarda una estrecha relación con el amurallamiento de muchas ciudades durante el siglo XII. La misión de este individuo consistía en vigilar las torres y adarves de la muralla desde la puesta del sol hasta el amanecer ${ }^{93}$. Los sobrevelas o rondadores supervisaban el correcto desempeño de esta importantísima función en los distintos sectores de la ciudad ${ }^{24}$. Si el rondador sorprendra al vigfa dormido en su puesto, éste sería sancionado con una multa que revertiría en beneficio del primero"s. Los sobrevelas hacían notar su presencia mediante una llamada que debfa ser convenientemente respondida por los centinelas a la tercera voz ${ }^{*}$.

Sin embargo, los concejos no sólo desarrollaron mecanismos de defensa pasiva, sino que también participaron directamente en las actividades bélicas. Como ya se ha señalado en páginas precedentes, el dominus villae, los alcaldes y el juez eran los encargados de dirigir la hueste o guerra ofensiva. Junto a ellos intervenfan los atalayeros, atajadores u oteadores, siempre presentes en los Fueros de las Extremaduras. Reclutados entre los vecinos de cada collación poseedores de caballo, estos personajes llevaban a cabo la exploración del territorio enemigo destacándose del núcleo o haz

quando todos amatassen el fuego, ellos abricron las puertas e entraron los enemigos ... En esta misma guisa deven curiar otrossi la villa en tiempo de coger las micses", J. GUTiERREZ CUADRADO, Op. cil. (nota 20), ep. 893, pp. 154-155. 635-637.

'R. DE UREÑa Y SMENJAUd, El Fuero de Cuenca, Op. cit. (nota 26), cap. XXX, II, pp.

${ }^{2}$ Sobradamente conocida es la polémica suscitada en tomo a la prioridad cronológica del Fuero de Teruel sobre el de Cucnca, sobre esta cuestión véanse: A.M“. BARRI:RO GARClA, El Fuero de Teruel. Su historia, proceso de formación y reconstrucción crílica de sus fuentes, Madrid, 1979, J. CARUANA, La prioridad cronológica del Fuero de Teruel sobre el de Cuenca, "AHDE", XXV (Madrid, 1989), pp. 791-798, del misino autor El Fuero Latino de Teruel, Teruel, 1974.

${ }^{93}$ M. GoRosCh, El Fuero de Teruel, Estocolmo, 1954, pp. 146.

Mbidem, pp. 145-146.

"9s Ibidem.

"Ibidem. Al parecer, los turcos ya emplcaban este canto o voz de alcrta para acreditar la preaencia del vigilante en su lugar, según ha subrayado $M$. GONZÁL.LZ. SIMANCAS, España militar a principios de la Baja Edad Media, Mudrid, 1925, p. 85. 
de la hueste ${ }^{97}$. Siempre se encontraban a las órdenes de los alcaldes y recibían su sueldo en función del mayor o menor éxito de la expedición: un buey o $4 \mathrm{mrs}$. si la campaña habla sido provechosa, $2 \mathrm{mrs}$. si el botín no había sido demasiado abundante, e incluso nada si no se habla obtenido ganancia alguna ${ }^{98}$. Además, tenían la obligación de entregar toda la soldada cuando sobreviniese algún mal a la hueste por su negligencia.

En el Fuero de Coria la figura del atalayero cobró especial importancia, pues estaba exento de pagar el quinto, consistente en la participación a que tenfa derecho el rey en el botín obtenido por la hueste en cada campaña ${ }^{99}$, esta cuota quedó establecida por influencia islámica en una quita parte de las ganancias, de ahi su nombre ${ }^{100}$. Asimismo, se recompensó a aquellos oteadores que en su peligrosa misión exploradora se arriesgaran a atravesar los grandes ríos de la región ${ }^{101}$; por ejemplo el Fuero de Coria premiaba a los que cruzasen el río Tajo ${ }^{102}$, y los Fueros de Cáceres y Usagre a los que pasasen el río Guadiana ${ }^{103}$. También en Béjar los atalayeros prestaban sus servicios a caballo y eran sustituídos por otros en caso de que el animal no estuviese en condiciones 6 ptimas $^{104}$, su soldada se fijaba conforme al botín obtenido en cada expedición ${ }^{105}$ y si se descuidaban en el ejercicio de sus funciones no recibran nada ${ }^{106}$.

Conviene recordar que el atalayero difería notablemente del simple vigfa. Sus atribuciones guardahan cierta semejanza con la anubda o

\footnotetext{
${ }^{97}$ R. DE UREÑA Y SMENJAUd, El Fuero de Cuenca, Op. cit. (nota 26), cap. XXX, VII, pp. 639-641.

${ }^{90}$ Ibidem, cap. XXX, VIII, p. 641. También en el Fuero de Coria se establece la misma noma, J. MALDONADO y FERNÁNDEZ DEL. TORCO, Op. cit. (nola 77), ep. 173, pp. 57-58.

99 "Todo ome de Coria e del su ternino que cavalgar e portar, de la quinta en Coria, fueras aquel qui estodier en la atalaya, o en trebcjo, o en el puerto, non de quinta; si hijos o inuger oviere, alla de la quinta en sus casticllos", J. MAIDONADO Y FIERNÁNDEZ DEL TORCO, Op. cit. (nota 77), cp. 176, p. 58.

${ }^{100} \mathrm{~L}$. Garcla di: ValdDiavlidano, Curso de Historia de las Instituciones, Op. cit. (nota 6), p. 609

${ }^{101}$ S. DE MOXO, El Derecho Militar, Op. cit. (nota 2), pp. 46-47.

102J. MALDONADO Y FieRnÁNDIZZ Dill TORCO, Op. cit. (nota 77), p. 42.

${ }^{103}$ P. LUMBreras VALILNTE, Op. cit. (nota 19), p. 67 y R. DE UREÑa y SMENJAUd \& A. BONILIA SAN MARTin, Fuero de Usagre, Op. cil. (nota 75), p. 205.

${ }^{104} \mathrm{~J}$. GutitrREZ CUADRADO, Op. cil. (nota 20), ep. 900, p. 156.

${ }^{105}$ Ibidein, ep. 901 , p. 156.

${ }^{106}$ Ibidein, ep. 902, p. 156
} 
vigilancia realizada lejos de la villa. $M^{2}$ Estela González ha definido esta última como una prestación orientada a satisfacer una necesidad colectiva de interés general en materia de seguridad. La anubda surgió con todas las características de un servicio público, es decir, con regularidad y continuidad para beneficio del interés común, y su exigencia correspondía a las instituciones estatales ${ }^{107}$. Obviamente, no se trataba de la misma realidad, pero se puede afirmar que tanto la anubda como las atalayas respondían al permanente estado de alerta en que se encontraban villas y ciudades, y a la necesidad de mantener la vigilancia ininterrumpida de la frontera. Asi, mientras el servicio de atalayas tenía un carácter eventual, la anubda era constante. La principal coincidencia reside en que ambas prestaciones se realizaban a caballo y tenfan como finalidad primordial garantizar la estabilidad del territorio. Frecuentemente, se recurrio a servicios de espionaje para recabar información sobre las posiciones y movimientos de los enemigos. Las personas que llevaban a cabo estas arriesgadas misiones eran designadas por el dominus y los alcaldes, y obtenfan una buena compensación económica como pago a su trabajo ${ }^{108}$.

Las fortalezas aparecen muy a menudo como objeto de conquista en los Fueros de las Extremaduras. El concejo de Cáceres tenía la obligación de tomar a los musulmanes los castillos de Trujillo, Santa Cruz y Medellín que Alfonso IX habra entregado como término a la ciudad ${ }^{109}$. Este precepto muestra la posición preeminente de esta villa así como su vocación fronteriza. En Usagre se premió la acción individual del caballero y del peón que se destacasen en el combate frente a una fortaleza ${ }^{110}$, lo que pone de manifiesto la tradición castrense de los fueros extremenos.

No obstante, es el Fuero de Cuenca el que hace mayor hincapié en esta cuestión y ofrece una casuística muy completa. Asi, el caballero o el peon que entrase primero en un castillo para tomarlo tendría derecho a un

\footnotetext{
${ }^{107} \mathrm{M}^{2}$.E. GONZALEZ, La anubda y la arrobda en Castilla, "CHE", XXXI-XL (Buenos Aires, 1964), pp. $5-42$. 643.

${ }^{100} R$. DE UREŃa Y SMenjaud, El Fuero de Cuenca, Op. cit. (nota 26), cap. XXX, XI, p.

${ }^{109 \mathrm{~m} M a n d o}$ etiam quod Concilium de Caceres non vadat ad juntas cum aliquibus Conciliis quando evenerint nisi ad pedem Pontis de Alconetara que usque sint recuperata ista castella: Trugiel, Sancta Cruz et Medellin; et post recuperacionem istorum ubi se advenerint cum aliis Conciliis", P. LUMBreras VALENTE, Op. cit. (nota 19), p. V.

${ }^{110}$ R. DE URENA Y SMENJAUd \& A. Bonilla SAN MARTIN, Fuero de Usagre, Op. cit. (nota 75), p. 178.
} 
moro de los que hubiese alli, si intervenfan dos o más personas en este hecho compartirían el botín a partes iguales ${ }^{111}$. El adalid cristiano podría escoger la mejor casa que hubiese en el recinto, este derecho también se extendía al adalid musulmán quien, además, podría redimir a todos sus parientes cautivos ${ }^{112}$. El castillo constitura un importante elemento de referencia en los combates mantenidos cuerpo a cuerpo, pues el caballero o peon que derribase a otro a las puertas de una fortaleza se quedaría con su espada, escudo o silla ${ }^{113}$; asimismo, la pérdida de las armas durante la guerra sería compensada con dinero: $2 \mathrm{mrs}$. por la lanza con pendón y $1 \mathrm{mr}$. por la lanza sin pendón $n^{114}$, mientras que el ganado obtenido después de la conquista de una villa $o$ de un castillo podía tomarse libremente ${ }^{115}$. Finalmente, la entrega de una fortaleza al enemigo entrañaba un delito de traición que se castigaba con la muerte por descuartizamiento ${ }^{116}$. Este acto se consideraba como un ataque directo a la autoridad real y por tanto un gesto de infidelidad hacia el monarca, quien asumía la aplicación de la pena al traidor ${ }^{117}$.

Numerosas localidades andaluzas recibieron después de su conquista el Fuero de Cuenca, que tuvo muy buena acogida en estas tierras a causa de su adaptación a unas realidades concretas y debido a la procedencia de los repobladores de este sector, originarios principalmente de Castilla la Nueva y de las Extremaduras ${ }^{118}$. Por este motivo, las coincidencias en materia de

\footnotetext{
"11" El cavallero o el peon que en castillo o en torre primeramente entrare, aya un moro de aquellos que y fueren ganados o fallados, e si dos o mas entraren en uno, ayalo aquel moro de comun", R. DE UREÑa Y SMENJAUD, El Fuero de Cuenca, Op. cit. (nota 26), cap. XXX, XXX, p. 653.

112" Qual quier que fuere xristiano o adalid e traxere hueste a castillo o a villa, si fuere preso, ayan una casa qual quiere con todas las cosas que alli fallare; e si moro fuere aya otrosi casa con las cosas que en ella fueren e todos sus parientes sean y salvos", bidem, cap. XXX, XV, p. 681 .

${ }^{113}$ bidem, cap. XXX, XXIX, p. 653.

${ }^{114}$ bidein, cap. XXX, XXXI, p. 653.

"Isidem, cap. XXXI, XVI, p. 683.

$116 " .$. otro si qual quiere que firiere al sennor dela çibdad o lo matare o castillo perdiere, sea partido por miembros", Ibidem, cap. XI, XV, p. 311.

${ }^{117}$ A. IGLESIA FERREROS, Historia de la traición. La traición regia en León y Castilla, Santiago de Compostela, 1975, pp. 104-109.

${ }^{118} \mathrm{M}$. GONZALEZ JIMÉNEZ, Gobiemo urbano, "Actas del IV Coloquio Intemacional de Historia Medieval de Andalucia. Las ciudades andaluzas (Siglos XIII-XVI)", Málaga, 1991, p. 14.
} 
organización militar y defensiva entre los Fueros concedidos a estos núcleos, en su mayor parte fronterizos, y el texto conquense son asombrosas, pero razones de espacio impiden realizar una aproximación más detallada a su contenido $^{119}$.

\section{CONCLUSIONES}

Los Fueros municipales se revelan como una fuente de primera magnitud para abordar el estudio de las cuestiones anteriormente señaladas. Castillos y fortalezas fueron elementos habituales en el paisaje medieval. Además, constituyeron la expresión más evidente del carácter bélico de una sociedad que florecio al amparo de estas construcciones militares. Esta realidad se acentuó especialmente en los reinos de Castilla y de Leon, donde la situación de guerra casi permanente conllevo una serie de necesidades defensivas, cuya principal consecuencia fue la multiplicación de las fortificaciones y la aparición de la tenencia de fortalezas, institución que también estuvo presente en otros reinos peninsulares. Los textos forales escogidos reflejan la importancia que adquirieron las fortificaciones en la vida cotidiana de las ciudades castellano-leonesas, no sólo como instrumentos defensivos, sino también como catalizadores de la realidad social y política del momento.

La monarquía desarrollo algunos mecanismos para ejercer su poder en el seno de los concejos y se sirvió principalmente de dos oficiales: el dominus villae y el alcaide, que desempeñaron en su nombre tareas de gobierno y asumieron la defensa de alcázares y demás construcciones defensivas respectivamente. Sin embargo, a través de los Fueros municipales se percibe una desigual evolución de ambos personajes; mientras que el dominus o tenente fue perdiendo muchas de sus atribuciones originales y desapareció del panorama concejil a mediados del siglo XIII, el alcaide no sólo se mantuvo en el ejercicio de sus funciones, sino que, además, alcanzó importantes cotas de poder al controlar el principal bastión defensivo urbano en nombre del rey, lo que explica que durante la Baja Edad Media la

\footnotetext{
${ }^{119} \mathrm{El}$ caso de Baeza y de Úbeda ha sido objeto de un estudio más ponnenorizado en $\mathrm{M}^{2} \mathrm{C}$. CASTRILL LLAMAS, Reflexiones en tomo a la normativa sobre organización militar y defensiva en los Fueros de Baeza y de Úbeda, "IV Jomadas Nacionales de Historia Militar. Fermando III el Santo y su época", Scvilla, 9/13 Mayo 1994, (en prensa).
} 
tenencia de fortalezas gozase de gran relevancia a nivel político y militar. Por otro lado, el palatium, símbolo de la primacía monárquica ante el concejo, se vacio progresivamente de su significado primitivo, aunque permaneció como morada regia en la ciudad.

En otro orden de cosas, a través de los textos forales estudiados se palpa la continua preocupación que supuso la conservación y mantenimiento de las fortificaciones, sobre todo en los concejos de las Extremaduras, donde se estableció una normativa muy precisa que pretendfa regular la ejecuc:ón de las obras de restauración de muros y castillos; asimismo, se fijó la utilización de numerosas calonas y penas judiciales que se invirtieron en la reparación de estos edificios, con lo que se buscaba garantizar la seguridad de los concejos situados en las proximidades de la frontera, más expuestos a los ataques enemigos.

Los servicios de vigilancia en castillos y fortalezas se perfeccionaron notablemente gracias a los progresos de la arquitectura castrense; de nuevo, los Fueros de las Extremaduras están cuajados de referencias a velas, vigías, rondadores, atalayeros y espías, cuyo desfallecimiento se penaba con asombrosa dureza. Por otro lado, esta reglamentación da una idea precisa del lugar que ocuparon las actividades bélicas en los concejos castellanos y leoneses de los siglos XI al XIII.

En definitiva, los textos forales analizados ofrecen una rica y variada normativa sobre las fortificaciones y otros aspectos afines que conviene tener muy presentes para estudiar los antecedentes institucionales de la tenencia de fortalezas, tanto desde el punto de vista jurídico como desde una perspectiva social. Asimismo, a lo largo del período estudiado se produjeron importantes transformaciones en el campo de la organización militar en los reinos de Castilla y de León, que tuvieron una plasmación concreta en el seno del sistema defensivo territorial, donde las fortificaciones jugaron un papel primordial.

\section{RÉSUMÉ}

Les Fueros municipaux castillans du $\mathrm{XI}^{\mathrm{em}}$ au XIII ture siccles fournissent une information assez riche sur les origines juridiques et institutionnelles de l'alcaidia de forteresses, institution à caractère militaire, dont l'objectif était de réglementer lé fonctionnement et gouvernement intérieur des châteaux du royaume. Bien que ces textes offrent encore une réglementation disperséc et asystématique, ils recueillent pour la première fois des 
dispositions organisant l'office d'alcaide, les services de surveillance. les travaux de réparation et d'entretien des fortifications, etc. Ces aspects scront par la suile élargis et améliorés avec la législation des Partidas ou de l'Espéculo. Les préceptes forales mettent aussi en relief l'importance des activités militaires au sein des concejos castellano-leoneses, coincidant avec une période de grande confrontation arméc entre les chrétiens et les musulmans.

\section{SUMMARY}

Castilian municipal ficeros from the eleventh to the thirteenth century provide important information on the legal origins of the alcaidia de fortalezas, a military institution set up primarily to control the internal administration and daily maintenance of all castles in the kingdom. Although the set of regulations contained in these documents is as yet unsystematic and lacking an overall coherence, nevertheless they do include the first examples of codes intended to define the post of the alcaide, the duties of castle watchmen, and the tasks of repairing and maintaining fortifications. These codes were later to be revised and expanded in the Partidas and the Especulo. Moreover, these early regulations reveal the fundamental importance which military activities had for the castilian-leonese concejos, an importance which coincided with a period of great conflict betwen Christian and Muslims. 